\title{
Teaching NeuroImage: Abducens Nerve Palsy With Ipsilateral Excessive Eye Tearing Attributed to an Internal Carotid Artery Sympathetic Plexus Schwannoma
}

Lina Palaiodimou, MD, Stefanos Lachanis, MD, Eleni Bakola, MD, Panagiotis Zis, MD, Evangelia Kararizou, MD, Marianna Papadopoulou, MD, and Georgios Tsivgoulis, MD

Neurology ${ }^{\circledR}$ 2021;97:e1461-e1463. doi:10.1212/WNL.0000000000012183

Figure 1 Neuroimaging Findings of a Patient With an Internal Carotid Sympathetic Plexus Schwannoma

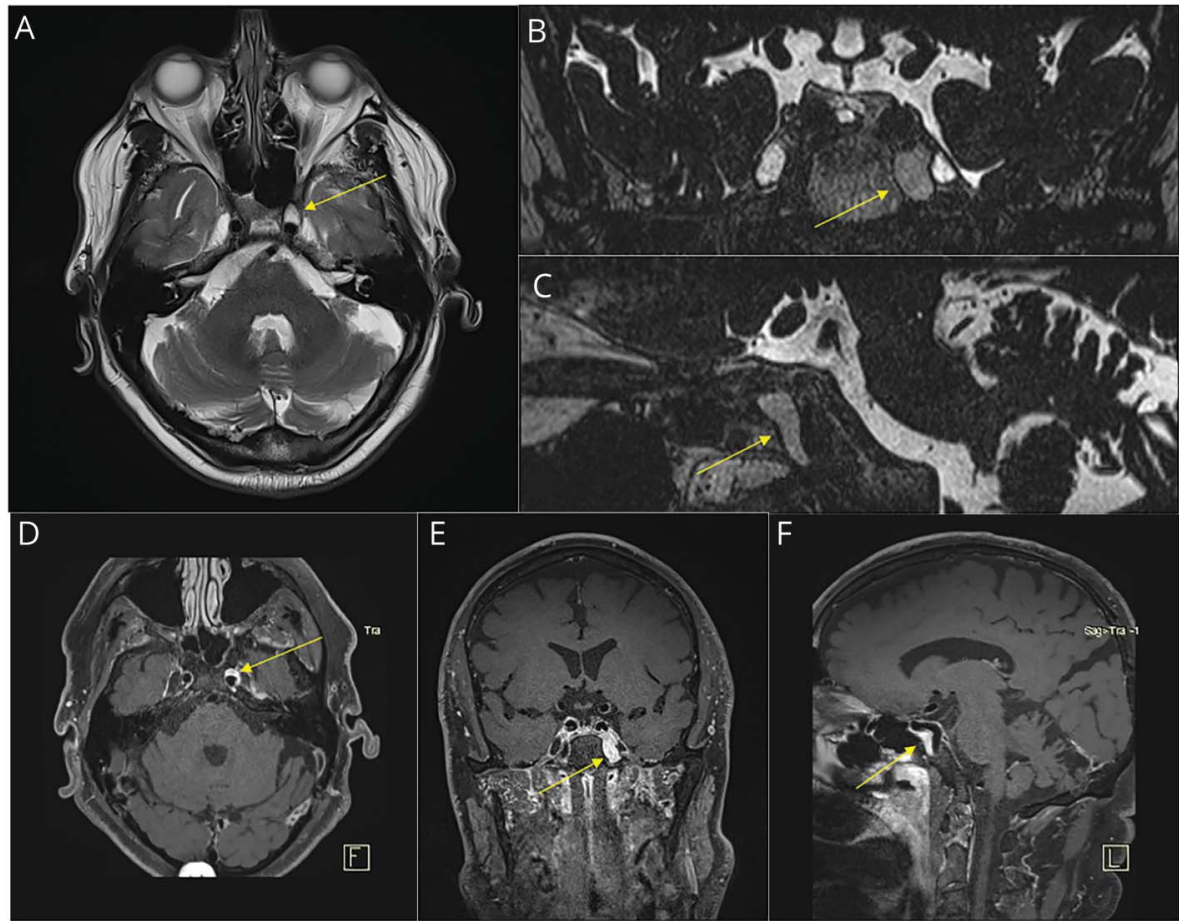

Axial brain MRI with T2-weighted sequence shows a hyperintense lesion along the anterior wall of the left internal carotid artery at the transition of the petrous to cavernous segment ( $A$, arrow). Coronal (B) and sagittal (C) brain MR with T2-weighted 3D turbo spin-echo (SPACE) sequence with multiplanar reconstruction demonstrate the elongated course of the lesion (arrows) within the left carotid canal, juxtapositionally to the internal carotid artery from the lower part of the cavernous segment until the midpart of the petrous segment. Axial (D), coronal (E), and sagittal (F) brain MRI with T1-weighted 3D SPACE black blood sequence show the homogeneously enhancing lesion (arrows) in the left carotid canal, surrounding the petrous and cavernous segments of the internal carotid artery.

A 65-year-old man developed subacute horizontal diplopia due to left abducens nerve (AN) palsy and excessive left eye tearing. Brain MRI revealed a hyperintense T2 lesion with an elongated course within the left carotid canal, presenting homogenous contrast enhancement (figure 1). The imaging findings were characteristic for an internal carotid artery sympathetic

\section{Correspondence}

Dr. Tsivgoulis

tsivgoulisgiorg@yahoo.gr

\section{MORE ONLINE}

Teaching slides

links.lww.com/WNL/

B416

From the Second Department of Neurology (L.P., E.B., M.P., G.T.), National and Kapodistrian University of Athens, School of Medicine, "Attikon" University Hospital; Iatropolis Magnetic Resonance Diagnostic Centre (S.L.), Athens; Medical School (P.Z.), University of Cyprus, Nicosia; First Department of Neurology (E.K.), National and Kapodistrian University of Athens, Aeginition Hospital; Department of Physiotherapy (M.P.), University of West Attica, Athens, Greece; and Department of Neurology (G.T.), the University of Tennessee Health Science Center, Memphis.

Go to Neurology.org/N for full disclosures. Funding information and disclosures deemed relevant by the authors, if any, are provided at the end of the article. 
Figure 2 Neuroimaging Findings of a Patient With Excessive Tearing Attributed to an Internal Carotid Sympathetic Plexus Schwannoma

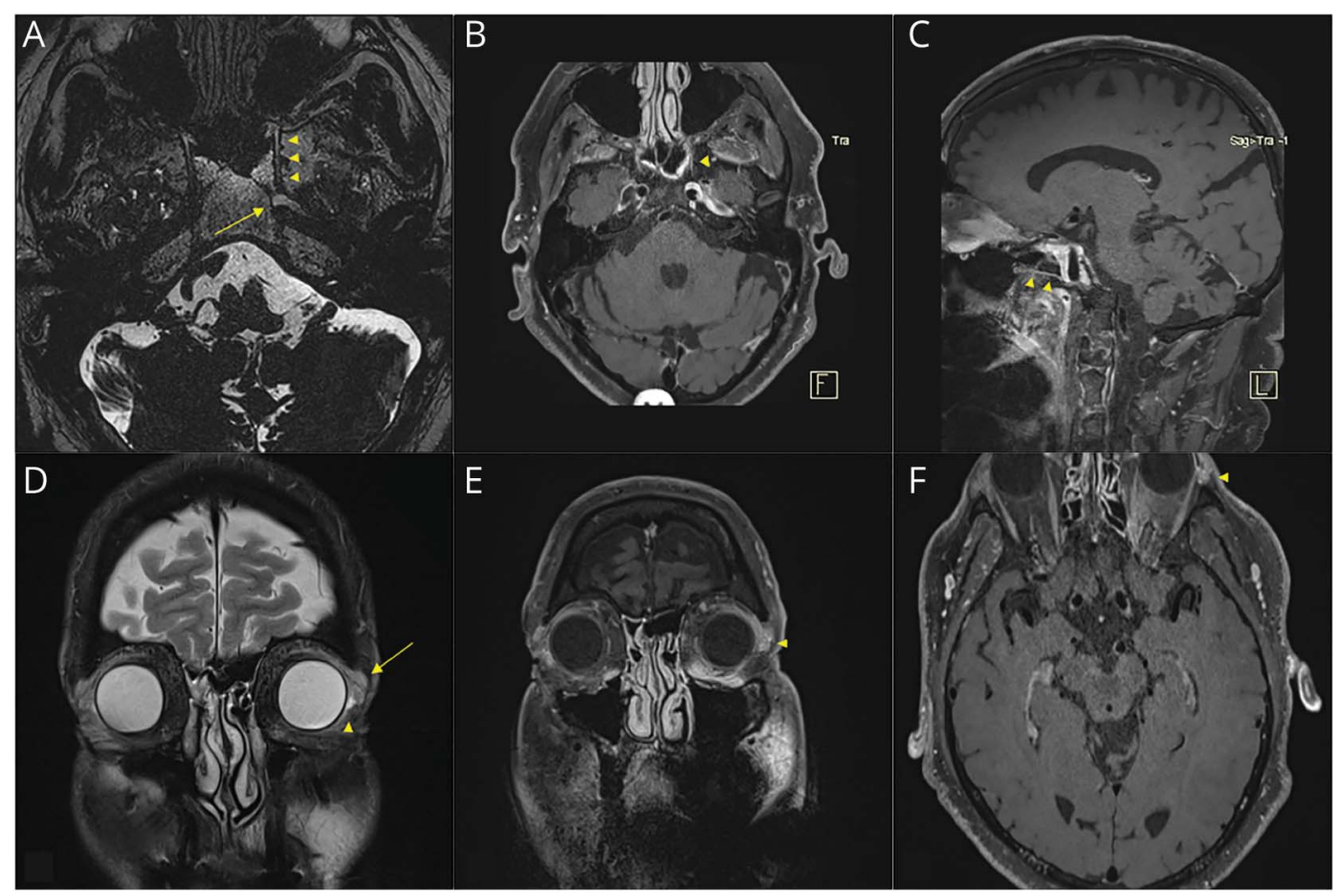

Axial brain MRI with T2-weighted 3D turbo spin-echo (SPACE) sequence with multiplanar reconstruction shows the Vidian nerve (A, arrowheads) within the pterygoid canal in close proximity to the internal carotid sympathetic plexus schwannoma (A, arrow). Axial (B) and sagittal (C) brain MRI with T1-weighted 3D SPACE black blood sequence demonstrate the left Vidian canal as an enhancing linear structure (arrowheads) at the level of the petrous segment of the internal carotid artery. Coronal brain MRI with T2-weighted sequence with fat saturation shows an edematous, enlarged left lacrimal gland ( $D$, arrow) compared to the healthy side and fluid accumulation in the left excretory lacrimal ducts (D, arrowhead). Coronal (E) and axial (F) brain MRI with T1-weighted 3D SPACE black blood sequence confirm the enlargement of the left lacrimal gland with more intense contrast enhancement (arrowheads) compared to the healthy side.

plexus (ICSP) schwannoma compressing the left AN. Subsequent irritation of the deep petrosal nerve originating directly from ICSP and continuing as the Vidian nerve may have led to the lacrimal gland edema and excessive left eye tearing (figure 2). Thorough case presentation and a figure demonstrating the relevant anatomy are available from Dryad at doi. org/10.5061/dryad.pzgmsbck6.

ICSP schwannoma represents an uncommon cause of AN palsy $^{1,2}$ that may also manifest with excessive ipsilateral eye tearing due to Vidian nerve involvement.

\section{Study Funding}

None to report.

\section{Disclosure}

The authors report no disclosures. Go to Neurology.org/N for full disclosures.

\section{Appendix Authors}

\begin{tabular}{|c|c|c|}
\hline Name & Location & Contribution \\
\hline $\begin{array}{l}\text { Lina } \\
\text { Palaiodimou, } \\
\text { MD }\end{array}$ & $\begin{array}{l}\text { National and Kapodistrian } \\
\text { University of Athens, Greece }\end{array}$ & $\begin{array}{l}\text { Data collection, analysis } \\
\text { and interpretation, } \\
\text { drafting and revising the } \\
\text { manuscript }\end{array}$ \\
\hline $\begin{array}{l}\text { Stefanos } \\
\text { Lachanis, MD }\end{array}$ & $\begin{array}{l}\text { latropolis Magnetic } \\
\text { Resonance Diagnostic } \\
\text { Centre, Athens, Greece }\end{array}$ & $\begin{array}{l}\text { Data collection, analysis } \\
\text { and interpretation, critical } \\
\text { comments during } \\
\text { manuscript revision }\end{array}$ \\
\hline $\begin{array}{l}\text { Eleni Bakola, } \\
\text { MD }\end{array}$ & $\begin{array}{l}\text { National and Kapodistrian } \\
\text { University of Athens, Greece }\end{array}$ & $\begin{array}{l}\text { Critical comments during } \\
\text { manuscript revision }\end{array}$ \\
\hline $\begin{array}{l}\text { Panagiotis Zis, } \\
\text { MD, PhD }\end{array}$ & $\begin{array}{l}\text { University of Cyprus, } \\
\text { Nicosia }\end{array}$ & $\begin{array}{l}\text { Critical comments during } \\
\text { manuscript revision }\end{array}$ \\
\hline $\begin{array}{l}\text { Evangelia } \\
\text { Kararizou, MD, } \\
\text { PhD }\end{array}$ & $\begin{array}{l}\text { National and Kapodistrian } \\
\text { University of Athens, Greece }\end{array}$ & $\begin{array}{l}\text { Critical comments during } \\
\text { manuscript revision }\end{array}$ \\
\hline
\end{tabular}




\begin{tabular}{lll} 
Appendix & (continued) & \\
\hline Name & Location & Contribution \\
\hline $\begin{array}{l}\text { Marianna } \\
\text { Papadopoulou, } \\
\text { MD, PhD }\end{array}$ & $\begin{array}{l}\text { National and Kapodistrian } \\
\text { University of West Attica, } \\
\text { Greece }\end{array}$ & $\begin{array}{l}\text { Critical comments during } \\
\text { manuscript revision }\end{array}$ \\
\hline $\begin{array}{l}\text { Georgios } \\
\text { Tsivgoulis, MD, } \\
\text { PhD }\end{array}$ & $\begin{array}{l}\text { National and Kapodistrian } \\
\text { Greece; The University of } \\
\text { Tennessee Health Science }\end{array}$ & $\begin{array}{l}\text { Data collection, analysis } \\
\text { and interpretation, } \\
\text { drafting and revising the } \\
\text { manuscript }\end{array}$ \\
& $\begin{array}{l}\text { Center, Memphis } \\
\end{array}$ & \\
\hline
\end{tabular}

\section{References}

1. Hamilton JD, Demonte F, Ginsberg LE. Imaging of carotid canal sympathetic plexus schwannoma. AJNR Am J Neuroradiol. 2011;32(7):1212-1215.

2. Türe U, Seker A, Kurtkaya O, Pamir MN. Internal carotid plexus schwannoma of the cavernous sinus: case report. Neurosurgery. 2003;52(2):435-438.

Marianna

Critical comments during

Data collection, analysis and interpretation

drafting and revising the Tennessee Health Science manuscript Center, Memphis 


\section{Neurology}

Teaching NeuroImage: Abducens Nerve Palsy With Ipsilateral Excessive Eye Tearing Attributed to an Internal Carotid Artery Sympathetic Plexus Schwannoma

Lina Palaiodimou, Stefanos Lachanis, Eleni Bakola, et al.

Neurology 2021;97;e1461-e1463 Published Online before print May 12, 2021

DOI 10.1212/WNL.0000000000012183

This information is current as of May 12, 2021

Updated Information \&
Services

References

Subspecialty Collections

Permissions \& Licensing

Reprints including high resolution figures, can be found at: http://n.neurology.org/content/97/14/e1461.full

This article cites 2 articles, 1 of which you can access for free at: http://n.neurology.org/content/97/14/e1461.full\#ref-list-1

This article, along with others on similar topics, appears in the following collection(s):

Diplopia (double vision)

http://n.neurology.org/cgi/collection/diplopia_double_vision MRI

http://n.neurology.org/cgi/collection/mri

Nerve tumor

http://n.neurology.org/cgi/collection/nerve_tumor

Information about reproducing this article in parts (figures,tables) or in its entirety can be found online at:

http://www.neurology.org/about/about_the_journal\#permissions

Information about ordering reprints can be found online:

http://n.neurology.org/subscribers/advertise

Neurology ${ }^{\circledR}$ is the official journal of the American Academy of Neurology. Published continuously since 1951, it is now a weekly with 48 issues per year. Copyright @ 2021 American Academy of Neurology. All rights reserved. Print ISSN: 0028-3878. Online ISSN: 1526-632X.

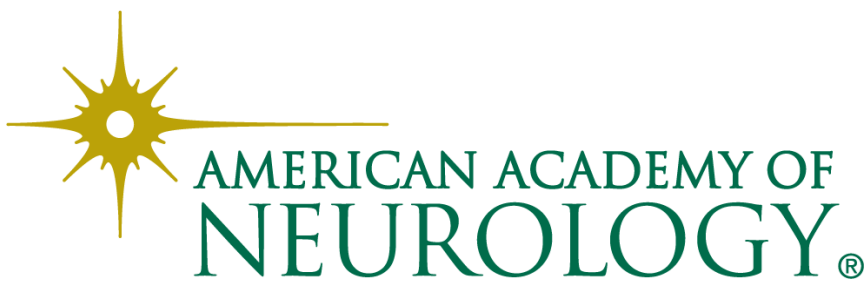

